\title{
Hubungan Harga Diri dan Optimisme dengan Kesejahteraan Subjektif pada Mahasiswa Magister Psikologi Universitas Medan Area
}

\section{The Relationship between Self-Esteem and Optimism with Subjective Wellbeing in Psychology Masters Students University of Medan Area}

\author{
Nur Afni Safarina, Abdul Munir \& Nur’aini \\ Program Studi Magister Psikologi, Program Pascasarjana, \\ Universitas Medan Area
}

\begin{abstract}
Abstrak
Penelitian ini bertujuan untuk mengetahui hubungan harga diri dan optimisme dengan kesejahteraan subjektif mahasiswa Magister Psikologi UMA. Penelitian ini menggunakan metode kuantitatif korelasional. Sampel penelitian ini berjumlah 75 mahasiswa magister psikologi UMA yang masih aktif dengan menggunakan teknik simple random sampling. Metode pengumpulan data dalam penelitian ini menggunakan tiga skala, yaitu skala Kesejahteraan subjektif, Skala harga diri dan skala optimisme. Analisis data menggunakan teknik Analisis Regresi Berganda. Hasil penelitian ini menunjukkan (1) ada hubungan positif yang signifikan antara harga diri dan optimisme dengan kesejahteraan subjektif, dimana koefisien $r_{x 12 y}=0,640$ dan $p=0,000$ dengan konstribusi sebesar 40,9\%. (2) ada hubungan positif yang signifikan antara harga diri dengan kesejahteraan subjektif, dimana koefisien $r_{x 1 y}=0,635$ dan $p=0,000$, konstribusi sebesar $40,3 \%$. (3) ada hubungan positif yang signifikan antara optimisme dengan kesejahteraan subjektif, dimana koefisien $r_{x 2 y}=0,414$ dan $p=0,000$, dengan konstribusi sebesar $17,1 \%$, dengan demikian dinyatakan bahwa seluruh hipotesis dapat diterima.

Kata kunci: Kesejahteraan Subjektif, Harga Diri, dan Optimisme
\end{abstract}

\section{Abstract}

The aim of this study was to determine and analyze the relationship of self-esteem and optimism with subjective wellbeing of UMA Master of Psychology students. The approad of this study was correlational quantitative method. The samples of this study were 75 UMA psychology masters who are still active taken by simple random sampling technique. Data collection methods in this study used three scales, namely the scale of subjective wellbeing, self-esteem scale and optimism scale. Data were analyzed with Multiple Regression Analysis technique. The results of this study indicate (1) there is a significant positive relationship between self-esteem and optimism with subjective well-being, where the coefficient $r \times 12 y=0.640$ and $p=0,000$ with contribution of $40.9 \%$. (2) there is a significant positive relationship between self-esteem and subjective well-being, where coefficient rx1y $=0.635$ and $p=0,000$, contribution of $40.3 \%$. (3) there is a significant positive relationship between optimism and subjective wellbeing, where the coefficient rx $2 y=0.414$ and $p=0,000$, with a contribution of $17.1 \%$, thus stated that all hypotheses are acceptable. Keywords: Subjective Wellbeing, Self-Esteem, and Optimism

How to Cite: Safarina, N.A. Munir, A. \& Nur'aini, (2019). Hubungan Harga Diri Dan Optimisme Dengan Kesejahteraan Subjektif Pada Mahasiswa Magister Psikologi Universitas Medan Area. Tabularasa: Jurnal Ilmiah Magister Psikologi, 1(1) 2019: 39-48,

${ }^{*}$ E-mail: safarina89psi@gmail.com

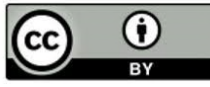


Nur Afni Safarina, Abdul Munir \& Nur'aini, Hubungan Harga Diri Dan Optimisme Dengan Kesejahteraan

\section{PENDAHULUAN}

Tema kesejahteraan subjektif merupakan tema yang sudah cukup banyak dibahas, tetapi belum banyak yang membahas kesejahteraan subjektif pada mahasiswa, yang tentunya memiliki prediktor kesejahteraan subjektif yang berbeda dari individu lainnya.

Pendidikan pada abad ke-21 berupaya menerapkan pendidikan yang positif dengan menerapkan psikologi positif dalam pendidikan. Pendidikan yang tidak membahagiakan tentunya bertentangan dengan tujuan pendidikan yang memberikan pengetahuan dan keterampilan sehingga dalam konteks kebahagiaan begaimana belajar dapat menjadi bahagia (Seligman, 2011).

Setiap orang menginginkan kesejahteraan di dalam hidupnya, bahkan Aristoteles (dalam Ningsih, 2013) menyebutkan bahwa kesejahteraan merupakan tujuan utama dari eksistensi hidup manusia. Setiap orang juga memiliki harapan-harapan yang ingin dicapai guna pemenuhan kepuasan dalam kehidupannya.

Individu yang memiliki kesejahteraan subyektif tinggi, ternyata merasa bahagia dan senang dengan teman dekat dan keluarga. Individu tersebut juga kreatif, optimis, kerja keras, tidak mudah putus asa, dan tersenyum lebih banyak daripada individu yang menyebut dirinya tidak bahagia (Argyle, dalam Nurhidayah \& Rini 2012).

Kesejahteraan subjektif merupakan salah satu kajian dalam psikologi positif, didefinisikan sebagai suatu fenomena yang meliputi evaluasi kognitif dan afektif hidup individu, seperti apa yang disebut orang pada umumnya sebagai kebahagiaan, ketentraman, berfungsi penuh, dan kepuasan hidup. Dengan demikian, kesejahteraan subjektif adalah konsep yang luas yang mencakup pengalaman menyenangkan, emosi positif, rendahnya tingkat suasana hati yang negatif, dan kepuasan hidup yang tinggi (Diener, Oishi \& Lucas, 2002, 2003).

Ada dua teori yang dapat digunakan untuk menjelaskan faktor-faktor yang menentukan kesejahteraan subjektif, yaitu top-down teori dan bottom-up teori. Top-down teori menjelaskan bahwa kesejahteraan subjektif dipengaruhi oleh faktor-faktor kepribadian, seperti harga diri, optimisme, neurotisme, sedangkan teori bottom-up menjelaskan bahwa kesejahteraan subjektif dipengaruhi oleh faktor situasional atau lingkungan, seperti: pekerjaan, keluarga, rekreasi, dan komunitas (Afiatin, 2009; (Nainggolan, dkk., 2017; Pandia, dkk., 2015).

Selanjutnya, penelitian yang dilakukan oleh Ariati (2010) menyebutkan lebih terperinci mengenai faktor-faktor yang mempengaruhi kesejahteraan subjektif yaitu: (1) harga diri positif, (2) Kontrol diri, (3) Ekstraversi, (4) Optimis, (5) Relasi sosial yang positif, (6) Memiliki arti dan tujuan hidup.

Diener, Suh, Lucas, dan Smith (1999) mengungkapkan bahwa kesejahteraan subjektif terdiri dari dua komponen, yaitu: (1) Afek, Merupakan gambaran evaluasi langsung individu atas peristiwa yang terjadi dalam hidupnya, individu akan merespon dengan afek positif jika mengalami sesuatu yang baik dan sebaliknya. Afek positif yang dominan cenderung direfleksikan sebagai kesejahteraan subjektif yang tinggi. (2) Kepuasan Hidup, Merupakan bentuk kemampuan individu untuk menikmati pengalaman disertai dengan kegembiraan. Penilaian kepuasan didasarkan pada perbandingan antara kondisi diri tertentu dibandingkan dengan berbagai standar, yang mencakup: orang lain, 
kondisi masa lalu, tingkat apresiasi dan ide dari kepuasan, dan kebutuhan atau tujuan lain.

Penelitian ini hanya membahas dua faktor yang mempengaruhi kesejahteraan subjektif yaitu harga diri dan optimisme. Harga diri merupakan suatu penilaian subjektif yang dibuat individu mengenai dirinya sendiri yang pada dasarnya positif atau negatif, apakah individu tersebut merasa bahwa dirinya berharga, penting, mampu dan memiliki arti bagi orang lain, yang berasal dari berbagai sumber baik internal maupun eksternal seperti dukungan keluarga, dan yang lain (Sudirman, 2015).

Harga diri merupakan aspek yang sangat penting pada mahasiswa, sebagian karena manusia memang sangat memperhatikan berbagai hal tentang diri, termasuk siapa dirinya, seberapa positif atau negatif seorang individu memandang dirinya, bagaimana citra yang ditampilkan pada orang lain, dan lain-lain (Byron \& Byrne,1994).

Menurut Coopersmith (1967) harga diri adalah evaluasi yang dibuat oleh individu terhadap dirinya dan biasanya dipertahankan dengan menghargai dirinya sendiri. Secara singkat harga diri adalah penilaian pribadi atas kelayakan yang diekspresikan melalui sikap individu terhadap dirinya. Harga diri juga merupakan penilaian subjektif yang disampaikan pada orang lain melalui laporan verbal dan tindakan ekspresif lainnya.

Coopersmith (1967) mengemukakan 4 sumber dalam harga diri, yaitu sebagai berikut: kekuasaan (power), keberartian (significance), kebajikan (virtue), dan kemampuan (competence).

Selanjutnya yaitu optimisme, pada umumnya optimis dimengerti sebagai keyakinan bahwa apa yang terjadi sekarang adalah baik, dan masa depan akan memberikan harapan yang kita angankan. Meski sedang menghadapi kesulitan, optimis tetap yakin bahwa kesulitan itu baik bagi pengembangan diri, dan di balik itu pasti ada kesempatan untuk mencapai harapan. Orang pesimis melihat kesulitan di setiap kesempatan, sedangkan orang optimis melihat kesempatan di setiap kesulitan.

Optimisme berasal dari bahasa Inggris yaitu optimism yang berarti keadaan selalu berpengharapan baik. Optimisme secara sederhana menurut Kamus Besar Bahasa Indonesia (2003) adalah; "paham (keyakinan) atas segala sesuatu dari segi baik dan menyenangkan; sikap selalu mempunyai harapan baik dan menyenangkan."

Mahasiswa yang optimis tidak memandang masalah sebagai akhir dari usahanya tetapi justru akan berusaha menyelesaikan dan keluar dari masalah tersebut. Individu (mahasiswa) dengan sifat optimisme yang tinggi cenderung lebih sehat karena memiliki keinginan untuk menjadi orang yang bisa menghasilkan sesuatu, memiliki harapan yang positif (Salamiah, dkk., 2011; Badri, 2011; Ginting, dkk., 2010).

Menurut Seligman (2006), optimisme adalah keyakinan individu bahwa peristiwa buruk/kegagalan hanya bersifat sementara, tidak mempengaruhi aktivitas dan tidak mutlak disebabkan diri sendiri tetapi bisa situasi, nasib atau individu lain. Individu yang optimis menganggap kegagalan disebabkan oleh sesuatu hal yang dapat diubah, sehingga dapat berhasil pada masa-masa mendatang. Individu yang pesimis menerima kegagalan sebagai kesalahanya sendiri, menganggapnya berasal dari pembawaan yang telah mendarah daging yang tidak dapat diubah (Munir, 2009; Wardani \& Wiwik, 2012; Sianturi, dkk., 2019; Sarwan, 2018). 
Menurut Seligman (2006) ada tiga dimensi cara menerangkan suatu peristiwa baik atau buruk terjadi untuk mengetahui individu tersebut pesimis atau optimis, yaitu: aspek permaenance, aspek pervasiveness, dan aspek personalization.

\section{METODE PENELITIAN}

Penelitian dilakukan di Kampus Pascasarjana Universitas Medan Area. Penelitian dilaksanakan selama dua bulan, yang dimulai sejak bulan Maret 2017 sampai dengan bulan April 2017. Populasi dalam penelitian ini adalah seluruh mahasiswa Magister Psikologi UMA yang masih aktif. Sampel dalam penelitian ini berjumlah 75 mahasiswa magister psikologi, yang diambil berdasarkan metode Slovin dengan taraf kesalahan 10\%. Pengumpulan data pada penelitian ini menggunakan tiga skala psikologi yaitu:

1) Skala kesejahteraan subjektif yang digunakan dalam penelitian ini disusun oleh Arbiyah, Imelda dan Oriza (2008) berdasarkan komponen penyusunan kesejahteraan subjektif yang dikemukakan oleh Diener yang terdiri dari 29 item.

2) Skala Harga Diri, yang disusun oleh Darmayanti (2012) dan dimodifikasi kembali oleh peneliti yang terdiri dari 25 item. Skala Harga Diri disusun berdasarkan sumber harga diri yang dikemukakan oleh Coopersmith (1967), yaitu kekuasaan (power), keberartian (significance), kebajikan (virtue), dan kemampuan (competence).

Skala Optimisme yang disusun oleh Darmayanti (2012) dan dimodifikasi kembali oleh peneliti. Skala optimisme disusun berdasarkan aspek-aspek optimisme yang dikemukakan oleh Seligman yaitu: aspek permaenance, aspek pervasiveness, dan aspek personalization.

\section{HASIL DAN PEMBAHASAN}

Uji normalitas sebaran di analisis dengan menggunakan uji Kolmogorov-Smirnov. Berdasarkan analisis tersebut, diketahui bahwa variabel Kesejahteraan Subjektif, Harga Diri dan Optimisme menyebar mengikuti sebaran normal, yaitu berdistribusi sesuai dengan prinsip kurve normal. Sebagai kriterianya apabila $\mathrm{p}>0,05$, maka sebarannya dinyatakan normal. Sebaliknya apabila apabila $\mathrm{p}<0,05$, maka sebarannya tidak normal (Hadi, 2000).

Tabel 1.

Rangkuman Hasil Perhitungan Uji Normalitas Sebaran

\begin{tabular}{lllllll}
\hline No & Var & Mean & SD & K-S & p & Ket \\
\hline 1 & KS & 54,48 & 4,872 & 0,541 & 0,93 & $\mathrm{~N}$ \\
\hline 2 & HD & 62,16 & 5,959 & 1,074 & 0,19 & $\mathrm{~N}$ \\
\hline 3 & Op & 69,57 & 6,500 & 0,698 & 0,71 & $\mathrm{~N}$ \\
\hline
\end{tabular}

Uji linieritas dimaksudkan untuk mengetahui derajat hubungan variabel Harga Diri dan Optimisme dengan Kesejahteraan Subjektif Mahasiswa. Sebagai kriterianya apabila p beda $<$ 0,05 maka dinyatakan mempunyai derajat hubungan yang linier (Hadi, 2000).

Tabel 2.

Uji Linieritas Hubungan

\begin{tabular}{llll}
\hline Linieritas & F Beda & P Beda & Ket \\
\hline $\mathrm{X}_{1,2}-\mathrm{Y}$ & $\mathbf{2 4 , 9 3 1}$ & o.ooo & Linier \\
\hline $\mathrm{X}_{1}-\mathrm{Y}$ & 49,304 & 0.000 & Linier \\
\hline $\mathrm{X}_{12}-\mathrm{Y}$ & $\mathbf{1 5 , 1 0 5}$ & 0.000 & Linier \\
\hline
\end{tabular}


Jadi, berdasarkan uji linieritas hubungan maka dapat dilihat dari tabel diatas ketiga variabel mempunyai derajat hubungan yang linier.

Berdasarkan hasil analisis dengan metode Regresi Berganda di dapatkan dua hasil dalam rangka menguji 3 hipotesis, yaitu sebagai berikut:

Tabel 3.

\begin{tabular}{llllll}
\multicolumn{6}{c}{ Rangkuman Perhitungan Multiple Regression } \\
\hline Var & R & r2) & p & BE\% & Ket \\
\hline X12 - Y & 0,640 & 0,409 & 0,000 & 40,9 & Sig \\
\hline X1 - Y & 0,635 & 0,403 & 0,000 & 40,3 & Sig \\
\hline X2 - Y & 0,414 & 0,171 & 0,000 & 17,1 & Sig \\
\hline
\end{tabular}

Berdasarkan tabel di atas, dapat diketahui bahwa:

a) Ada hubungan positif yang signifikan antara harga diri dan optimisme dengan kesejahteraan subjektif, dimana koefisien $r_{x 12 y}=0,640$ dengan $p=0,000$, hal ini berarti semakin tinggi harga diri dan optimisme maka semakin tinggi juga kesejahteraan subjektif.. Koefisien determinan $\left(\mathrm{r}^{2}\right)$ yang diperoleh dari hubungan antara prediktor harga diri dan optimisme dengan kesejahteraan subjektif adalah sebesar $\mathrm{r}^{2}=0,409$. Ini menunjukkan bahwa kesejahteraan subjektif dibentuk oleh harga diri dan optimisme dengan konstribusi sebesar 40,9\%.

b) Ada hubungan positif yang signifikan antara harga diri dengan kesejahteraan subjektif, dimana koefisien $r_{x 1 y}=0,635$ dengan $p=0,000$, hal ini berarti semakin tinggi harga diri maka semakin tinggi kesejahteraan subjektif. Koefisien determinan $\left(\mathrm{r}^{2}\right)$ yang diperoleh dari hubungan harga diri dengan kesejahteraan subjektif adalah sebesar $r^{2}=0,403$. Ini menunjukkan bahwa kesejahteraan subjektif dibentuk oleh harga diri dengan konstribusi sebesar 40,3\%.

c) Ada hubungan positif yang signifikan antara optimisme dengan kesejahteraan subjektif, dimana koefisien $r_{x 2 y}=0,414$ dengan $p=0,000$, hal ini berarti semakin tinggi optimisme maka semakin tinggi kesejahteraan subjektif. Koefisien determinan $\left(\mathrm{r}^{2}\right)$ dari hubungan antara optimisme dengan variabel terikat kesejahteraan subjektif adalah sebesar $r^{2}=0,171$. Ini menunjukkan bahwa kesejahteraan subjektif dibentuk oleh optimisme dengan konstribusi sebesar 17,1\%.

Tabel 4 .

Hasil Perhitungan Nilai Rata-rata Hipotetik dan Nilai Rata-rata Empirik

\begin{tabular}{lllll}
\hline \multirow{2}{*}{ Var } & \multirow{2}{*}{ SD } & \multicolumn{2}{c}{ Nilai Rata-Rata } & \multirow{2}{*}{ Ket } \\
\cline { 3 - 4 } & & Hipoteti & Empirik & \\
\hline KS & 4,872 & 42,5 & 54,48 & Tinggi \\
\hline HD & 5,959 & 50 & 62,16 & Tinggi \\
\hline Op & 6,500 & 52,5 & 69,57 & Tinggi \\
\hline
\end{tabular}

Berdasarkan tabel 4. diketahui bahwa mahasiswa yang menjadi responden penelitian memiliki kesejahteraan subjektif yang tergolong tinggi, begitu juga dengan harga diri dan optimisme mahasiswa tersebut.

Tujuan dari penelitian ini adalah untuk mengetahui hubungan harga diri dan optimisme dengan kesejahteraan subjektif mahasiswa magister psikologi. Proses pelaksanaan penelitian yang telah dilakukan di Prodi Pascasarjana Magister Psikologi UMA berjalan dengan lancar sesuai dengan perencanaan semula. Penelitian yang dilakukan dengan menggunakan metode penelitian kuantitatif melalui angket untuk 
pengumpulan data, selanjutnya dilakukan suatu pengujian untuk memberi gambaran tentang variabel penelitian. Selain itu pengukuran ini bertujuan untuk mengetahui ketepatan hasil penelitian dengan hipotesis yang diajukan oleh peneliti.

Berdasarkan hasil pengujian data-data penelitian yang telah dilakukan oleh peneliti, berikut ini akan dipaparkan pembahasan hasil penelitian yang diperoleh dari masing-masing variabel yaitu kesejahteraan subjektif mahasiswa magister, harga diri dan optimisme.

Hasil penelitian ini menggambarkan ada hubungan positif yang signifikan antara harga diri dan optimisme dengan kesejahteraan subjektif, dimana koefisien $r_{x 12 y}=0,640$ dengan $p=0,000$, hal ini berarti semakin tinggi harga diri dan optimisme maka semakin tinggi juga kesejahteraan subjektif.. Koefisien determinan $\left(\mathrm{r}^{2}\right)$ yang diperoleh dari hubungan antara prediktor harga diri dan optimisme dengan kesejahteraan subjektif adalah sebesar $r^{2}=0,409$. Ini menunjukkan bahwa kesejahteraan subjektif dibentuk oleh harga diri dan optimisme dengan konstribusi sebesar 40,9\%.

Hasil penelitian ini didukung oleh teori Top-down yang menjelaskan bahwa kesejahteraan subjektif dipengaruhi oleh faktor-faktor kepribadian, seperti harga diri, optimisme dan neurotisme. Teori ini menjelaskan bahwa kesejahteraan subjektif yang dialami seseorang tergantung dari cara individu tersebut mengevaluasi dan menginterpretasi suatu peristiwa/kejadian dalam sudut pandang yang positif. Perspektif teori ini menganggap bahwa, individu lah yang menentukan atau memegang peranan apakah peristiwa yang dialaminya akan menciptakan kesejahteraan psikologis bagi dirinya. Pendekatan ini mempertimbangkan jenis kepribadian, sikap, dan cara-cara yang digunakan untuk menginterpretasi suatu peristiwa. Sehingga untuk meningkatkan kesejahteraan subjektif diperlukan usaha yang berfokus pada mengubah persepsi, keyakinan dan sifat kepribadian seseorang (Ariati, 2010).

Selanjutnya hasil dari main effect pertama menunjukkan bahwa ada hubungan positif yang signifikan antara harga diri dengan kesejahteraan subjektif, dimana koefisien $r_{x 1 y}=0,635$ dengan $p=0,000$, hal ini berarti semakin tinggi harga diri maka semakin tinggi kesejahteraan subjektif. Koefisien determinan $\left(\mathrm{r}^{2}\right)$ yang diperoleh dari hubungan harga diri dengan kesejahteraan subjektif adalah sebesar $r^{2}=0,403$. Ini menunjukkan bahwa kesejahteraan subjektif dibentuk oleh harga diri dengan konstribusi sebesar 40,3\%, sedang sisanya dipengaruhi oleh faktor-faktor lain.

Hasil penelitian ini didukung oleh teori yang dikemukakan Diener bahwa tingkat kesejahteraan subjektif sendiri dipengaruhi oleh beberapa faktor, salah satunya, yaitu harga diri. Harga diri berpengaruh kepada kehidupan pribadi seseorang pada kehidupan sehari-hari. Lebih lanjut Myers dan Diener (1995) menjelaskan bahwa empat sifat batin yang mempengaruhi kesejahteraan subjectif atau pada seseorang adalah harga diri, rasa kontrol pribadi, optimisme, extravensi. Jadi dapat dikatakan bahwa harga diri memiliki peran penting dalam meningkatkan kesejahteraan subjektif seseorang khususnya mahasiswa.

Harga diri merupakan salah satu yang mempengaruhi kesejahteraan subjektif. Harga diri disini adalah bagaimana seorang mahasiswa magister menilai kehidupan dirinya sendiri positif secara keseluruhan. Harga diri positif yang dirasakan seorang 
mahasiswa magister juga dipengaruhi oleh alasan mereka ketika melanjutkan kuliah magister atau pascasarjana. Sedangkan kesejahteraan subjektif disini termasuk kepuasan hidup, afek positif dan afek negatif. Mahasiswa magister yang merasakan kesejahteraan subjektif hidupnya mereka memiliki kepuasan hidup yang tinggi, afek positif yang tinggi dan rendahnya afek negatif. Penilaian positif itu juga dapat menimbulkan afek-afek positif dalam diri mahasiswa tersebut. Mereka akan lebih merasakan perasaan senang dibandingkan dengan perasaan yang tidak menyenangkan. Menjadi mahasiswa magister merupakan hal yang membuat dirinya merasa lebih bangga dengan diri dan kehidupannya setelah menjadi mahasiswa pascasarjana.

Hasil temuan dari main effect kedua menunjukkan bahwa ada hubungan positif yang signifikan antara optimisme dengan kesejahteraan subjektif, dimana koefisien $r_{x 2 y}=$ 0,414 dengan $p=0,000$, hal ini berarti semakin tinggi optimisme maka semakin tinggi kesejahteraan subjektif. Koefisien determinan $\left(\mathrm{r}^{2}\right)$ dari hubungan antara optimisme dengan variabel terikat kesejahteraan subjektif adalah sebesar $r^{2}=0,171$. Ini menunjukkan bahwa kesejahteraan subjektif dibentuk oleh optimisme dengan konstribusi sebesar $17,1 \%$, sedang sisanya lebih besarnya dipengaruhi oleh faktor-faktor lain.

Hasil penelitian ini juga didukung oleh teori Top-down yang menjelaskan kesejahteraan subjektif yang dialami seseorang tergantung dari cara individu tersebut mengevaluasi dan menginterpretasi suatu peristiwa/kejadian dalam sudut pandang yang positif (Ariati, 2010).

Orang-orang optimis jarang merasa terkejut oleh kesulitan. Mereka merasa yakin memiliki kekuatan untuk menghilangkan pemikiran negatif, berusaha meningkatkan kekuatan diri, menggunakan pemikiran yang inovatif untuk menggapai kesuksesan, dan berusaha gembira, meskipun tidak dalam kondisi bahagia (Diener, 2002).

Menurut Scheiver dan Carter (dalam Nurtjahjanti, 2011) individu yang optimis akan berusaha menggapai pengharapan dengan pemikiran positif, yakni akan kelebihan yang dimiliki. Individu yang penuh optimis biasanya biasa bekerja keras menghadapi stres dan tantangan sehari-hari secara efektif, berdoa, dan mengakui adanya faktor keberuntungan dan faktor lain yang mendukung keberhasilannya. Individu yang optimis memiliki impian untuk mencapai tujuan, berjuang dengan sekuat tenaga, dan tidak ingin duduk berdiam diri menanti keberhasilan yang diberikan oleh orang lain. Individu optimis ingin melakukan sendiri segala sesuatunya dan tidak ingin memikirkan keberhasilan sebelum mencobanya.

Hasil penelitian ini sejalan dengan teori yang menyatakan bahwa optimisme merupakan salah satu faktor yang mempengaruhi kesejahteraan subjektif. Salah satu keberhasilan bagi mahasiswa dalam menyelesaikan studinya adalah sikap positif, yaitu merasa yakin bahwa masalah yang dihadapi dapat teratasi. Paling tidak mahasiswa harus merasa yakin akan menemukan pemecahan masalah untuk memperoleh hasil terbaik yang mungkin dicapai dalam kondisi yang ada tanpa merasa takut gagal (Ginting, 2005). Ketika mengalami kegagalan, orang optimis cenderung menyingkapinya dengan respon yang aktif dan tidak putus harapan, merencanakan suatu tindakan, atau berusaha mencari pertolongan dan nasehat. Orang yang optimis juga menganggap kegagalan 
Nur Afni Safarina, Abdul Munir \& Nur'aini, Hubungan Harga Diri Dan Optimisme Dengan Kesejahteraan

disebabkan oleh sesuatu hal yang dapat diubah sehingga mereka dapat berhasil di masamasa yang akan datang (Seligman dalam Goleman, 2005).

\section{SIMPULAN}

Ada hubungan positif yang signifikan antara harga diri dan optimisme dengan kesejahteraan subjektif, dimana koefisien $r_{x 12 y}=0,640$ dengan $p=0,000$ dan $r^{2}=0,409$, hal ini menunjukkan bahwa kesejahteraan subjektif dibentuk oleh harga diri dan optimisme dengan konstribusi sebesar 40,9\%. Dari hasil ini diketahui bahwa masih terdapat 59,1\% pengaruh dari faktor lain terhadap kesejahteraan subjektif.

Ada hubungan positif yang signifikan antara harga diri dengan kesejahteraan subjektif, dimana koefisien $r_{x 1 y}=0,635$ dengan $p=0,000$, dan $r^{2}=0,403$. Ini menunjukkan bahwa kesejahteraan subjektif dibentuk oleh harga diri dengan konstribusi sebesar 40,3\%. Dari hasil ini diketahui bahwa masih terdapat 59,7\% pengaruh dari faktor lain terhadap kesejahteraan subjektif.

Ada hubungan positif yang signifikan antara optimisme dengan kesejahteraan subjektif, dimana koefisien $r_{x 2 y}=0,414$ dengan $p=0,000$, dan $r^{2}=0,171$. Ini menunjukkan bahwa kesejahteraan subjektif dibentuk oleh optimisme dengan konstribusi sebesar 17,1\%. Dari hasil ini diketahui bahwa masih terdapat 82,9\% pengaruh dari faktor lain terhadap kesejahteraan subjektif.

\section{DAFTAR PUSTAKA}

Afiatin, T. (2009). Subjective Well-Being of Aceh Adolescents after Tsunami: The meaning of Disaster and Adolescent Happiness. Yogyakarta: Universitas Gadjah Mada. Anima. Indonesian Psychological Journal. 2009, vol. 25, No. 1, 11-29

Arbiyah, N., Imelda, F.N,. Oriza, I.D. (2008). Hubungan bersyukur dan subjective well being pada penduduk miskin. Universitas Indonesia. Vol. 14 No. 01 januari 2017.

Ariati, J. (2010). Subjective Well-Being (Kesejahteraan Subjektif) dan Kepuasan Kerja pada Staf Pengajar (Dosen) di Lingkungan Fakultas Psikologi Universitas Diponegoro. Semarang: Universitas Diponegoro. Jurnal Psikologi Undip. Vol 8, No. 2, Januari 2017.

Azwar, S. (2007). Reliabilitas dan Validitas. Yogyakarta: Pustaka Pelajar.

Azwar, S. (2009). Metode Penelitian. Yogyakarta: Pustaka Pelajar.

Azwar, S. (2010). Penyusunan Skala Psikologi. Yogyakarta: Pustaka Pelajar.

Badri, M., Azhar A., (2011), Pengaruh Locus Of Control dan Harga Diri terhadap Motivasi Kerja Pegawai Dinas Pendidikan Kota Medan, Analitika: 3 (1): 29-36

Compton, W.C. (2001). Toward a tripartite factor structure of mental health: Subjective well-being, personal growth, and religiosity. The Journal of Psychology 13 $5(5), 486-500$.

Coopersmith, S. (1967). The Antecedent of Self Esteem. San Fransisco: Freeman.

Darmayanti, N. (2012). Model kesejahteraan Subjektif remaja Penyintas Bencana Tsunami Aceh 2004. Yogyakarta: Universitas Gajah Mada. Disertasi.

Diener, E., Lucas, Richard. E., \& Oishi, S. (2005). Subjective Well Being: The Science of Happiness and Life Satisfaction. dalam C.R. Snyder \& S.J. Lopez (eds.), Handbook of Positive Psychology (hal. 63-73). New York: Oxford University Press.

Diener, E.; Suh, E. M.; Lucas, R. E.; And Smith, H. L. (1999) “Subjective Well-being: Three Decades of Progress." Psychological Bulletin 125, no. 2(1999): 276-302.

Diener, E; Oishi, S; Lucas, R.E. (2003). Personality, Culture, and Subjective Well-Being; emotional and Cognitive Evaluations of Life. Annu. Rev. Psychol. 2003. 54: 403-25. 
Diener, Ed, (2000). Subjective Well-Being, the science of Happiness and a proposal for a national index. New York: American Psychologist Association. Vol.55, No.1, 34-43. Diakses Januari 2017d ari http://internal.psychology.illinois.edu/ broberts/ Diener\%202000.pdf

Diener, Ed.; Lucas R.E.; Oishi, S. (2002), Handbook of Positive Psychology (Chapter5). New York: Oxford University Press.

Ginting, E.M., Rahmi L., (2010), Hubungan antara Harga Diri dan Tingkat Pendidikan dengan Sikap Penerimaan Ibu terhadap Anak Autis Di Yayasan I-Home Schooling Medan, Analitika: 2 (1): $37-44$

Hadi, S. (2001). Statistik, Jilid 2. Yogyakarta: Andi

Kholidah, E.N. dan Alsa, A. (2012). Berpikir Positif untuk Menurunkan Stres Psikologis. Jurnal Psikologi. Volume 39, no. 1, juni: 67-75.

Lopez, S. J., Snyder, C. R. (2003). Positive Psychology Assesment: a handbook of models and measure (1th Ed), The Measurement and Utility of adult Subjective well-being, APA.

Munir, A., (2009), Hubungan Kepercayaan Diri dan Harga Diri dengan Kemampuan Bergaul Mahasiswa FIP UNIMED, Analitika: 1 (2): 1-9

Munir, A., (2009), Hubungan Kepercayaan Diri dan Harga Diri dengan Kemampuan Bergaul Mahasiswa FIP UNIMED, Analitika: 1 (2): 1-9

Nainggolan, W.S.. Chandra, A., \& Sembiring, S.A. (2017). Hubungan Dukungan Sosial dengan Harga Diri pada Mantan Pengguna Narkoba, Jurnal Diversita, 3 (2): 94-100

Nasfiannor, M.R \& Triana P. (2004). Hubungan Antara Komitmen Beragama Dan Subjective Well-Being Pada Remaja Akhir Di Univesitas Tarumanegara. Universitas Tarumanegara. Jurnal Psikologi Vol. 2 No. 1, Juni 2004.

Ningsih, D.A. (2013). Subjective Well-Being Ditinjau Dari Faktor Demografi (Status Pernikahan, Jenis Kelamin, Pendapatan). Jurnal Online Psikologi Vol. 01 No. 02, Thn. 2013. Diakses dari http://ejournal.umm.ac.id. Pada tanggal 10 Januari 2017.

Nurhidayah, S \& Rini A. (2012). Kebahagiaan Lansia Di Tinjau Dari Dukungan Sosial Dan Spiritualitas. Jurnal Soul, Vol. 5, No.2, Januari 2017.

Pandia, W.H, Abdul M., Azhar A., (2015) Hubungan Harga Diri Siswa dan Pola Asuh Demokratis Orangtua dengan Motivasi Belajar Siswa, Analitika: 7 (2): 80-87

Prawitasari, J, P. (2011). Psikologi Klinis: Pengantar Terapan Mikro \& Makro. Jakarta: Erlangga.

Prawitasari, J. P. (2012). Psikologi Terapan melintas batas Disiplin Ilmu. Jakarta: Erlangga.

Priyatno, D. (2011). Buku Saku SPSS, Analisis Statistik Data Lebih Cepat, Efisien dan Akurat.Yogyakarta: MediaKom

Putri, T, M; Sutarmanto, H. (2009). Kesejahteraan Subjektif waria pekerja seks komersial (PSK). Psikodinamika, Vol II, No.2. Universitas Gadjah mada.

Safaria, T. (2007). Optimismtic Quotient. Yogyakarta: Pyramid Publisher

Salamiah S, N.S., Dini H.S., (2011), Hubungan Intelegensi Dan Pola Asuh Orangtua Demokratis Dengan Harga Diri Siswa, Analitika: 3 (2): 99-114

Sarwan, A. (2018). Pengaruh Bimbingan Kelompok dan Harga Diri terhadap Kepercayaan Diri Siswa Kelas X SMAN 5 Takengon Aceh Tengah. JURNAL DIVERSITA, 4(1), 32-40. doi:https://doi.org/10.31289/diversita.v4i1.1603

Sarwan, A. (2018). Pengaruh Bimbingan Kelompok dan Harga Diri terhadap Kepercayaan Diri Siswa Kelas X SMAN 5 Takengon Aceh Tengah. JURNAL DIVERSITA, 4(1), 32-40. doi:https://doi.org/10.31289/diversita.v4i1.1603

Sarwono, S. W., \& Meinarno, E. A. (2009). Psikologi sosial. Jakarta: Salemba Humanika.

Seligman, M. (2011). Flourish. Toronto: Free Press.

Seligman, Martin E.P. (2006). Learned Optimism: How to Change Your Mind and Your Life. New York: Vintage Books

Sianturi, J., Marpaung, W., \& Manurung, Y. (2019). Perilaku Konsumtif Ditinjau Dari Harga Diri Pada Siswa-Siswi SMA Negeri 4 Medan. JURNAL DIVERSITA, 5(1), 58-66. doi:https://doi.org/10.31289/diversita.v5i1.2375

Sianturi, J., Marpaung, W., \& Manurung, Y. (2019). Perilaku Konsumtif Ditinjau Dari Harga Diri Pada Siswa-Siswi SMA Negeri 4 Medan. JURNAL DIVERSITA, 5(1), 58-66. doi:https://doi.org/10.31289/diversita.v5i1.2375 
Sudirman. (2015). Harga Diri Mahasiswa S1 dan S2 Universitas Muhammadiyah Malang. Seminar Psikologi \& Kemanusiaan. Psychology Forum UMM, ISBN: 978-979-796-324-8.

Sugiono. (2008). Metode Penelitian Pendidikan. Bandung: CV. Alfabeta.

Utami, M.S. (2009). Keterlibatan dalam Kegiatan dan Kesejahteraan Subjektif mahasiswa. Yogyakarta: Universitas Gadjah Mada. Jurnal Psikologi. Volume 36, No.2 Desember 2009; 144-163.

Wardani, A., Wiwik S., (2012), Cognitive Behavioural Therapy (CBT) untuk Meningkatkan Kesejahteraan Psikologis Remaja Gay, Analitika: 4 (2): 49-52

Wardani, A., Wiwik S., (2012), Cognitive Behavioural Therapy (CBT) untuk Meningkatkan Kesejahteraan Psikologis Remaja Gay, Analitika: 4 (2): 49-52 